Article

\title{
Licorice, Doum, and Banana Peel Extracts Inhibit Aspergillus flavus Growth and Suppress Metabolic Pathway of Aflatoxin B1 Production
}

\author{
Nesrine H. Youssef ${ }^{1}$, Sameer H. Qari ${ }^{2}{ }^{(D}$, Saleh Matar ${ }^{3,4}$, Najwa A. Hamad ${ }^{5}$, Eldessoky S. Dessoky ${ }^{6}{ }^{(D)}$, \\ Moustafa M. Elshaer ${ }^{7}$, Sherien Sobhy ${ }^{8}$, Ahmed Abdelkhalek ${ }^{8, * \mathbb{D}}$, Hossam M. Zakaria ${ }^{9}$, Ahmed A. Heflish ${ }^{10}$, \\ Ibrahim A. Elsamra ${ }^{10}$ and Said I. Behiry ${ }^{10}$
}

1 Microbiology and Mycotoxins Labs, Regional Center for Foods and Feeds, Agricultural Researches Center, Alexandria 12619, Egypt; nesrine_hassan66@yahoo.com

2 Biology Department, Al-Jumum University College, Umm Al-Qura University, Mecca 25376, Saudi Arabia; shqari@uqu.edu.sa

3 Chemical Engineering Department, Faculty of Engineering, Jazan University, Jazan 45142, Saudi Arabia; salehmatar@yahoo.com

4 Bioprocess Development Department, Genetic Engineering and Biotechnology Research Institute (GEBRI), City of Scientific Research and Technological Applications (SRTA-City), New Borg El-Arab City, Alexandria 21934, Egypt

check for updates

Citation: Youssef, N.H.; Qari, S.H.; Matar, S.; Hamad, N.A.; Dessoky, E.S.; Elshaer, M.M.; Sobhy, S.; Abdelkhalek, A.; Zakaria, H.M.; Heflish, A.A.; et al. Licorice, Doum, and Banana Peel Extracts Inhibit Aspergillus flavus Growth and Suppress Metabolic Pathway of Aflatoxin B1 Production. Agronomy 2021, 11, 1587. https://doi.org/10.3390/ agronomy 11081587

Academic Editors: Carla Ceoloni, Silvio Tundo and

Ljiljana Kuzmanović

Received: 14 July 2021

Accepted: 6 August 2021

Published: 10 August 2021

Publisher's Note: MDPI stays neutral with regard to jurisdictional claims in published maps and institutional affiliations.

Copyright: (c) 2021 by the authors. Licensee MDPI, Basel, Switzerland. This article is an open access article distributed under the terms and conditions of the Creative Commons Attribution (CC BY) license (https:// creativecommons.org/licenses/by/ $4.0 /)$.
5 Plant Protection Department, Faculty of Agriculture, Omar Al-Mukhtar University, Al Bayda 00218-84, Libya; najwa_a.ibrahim@yahoo.com

6 Department of Biology, College of Science, Taif University, P.O. Box 11099, Taif 21944, Saudi Arabia; es.dessouky@tu.edu.sa

7 Department of Microbiology at Specialized Medical Hospital, Mansoura University, Mansoura 35516, Egypt; dr_moustafa_elshaer@yahoo.com

8 Plant Protection and Biomolecular Diagnosis Department, ALCRI, City of Scientific Research and Technological Applications, New Borg El Arab City, Alexandria 21934, Egypt; sherienmorsey4@gmail.com

9 Agricultural Genetic Engineering Research Institute, Agricultural Research Center, Giza 12619, Egypt; hossam_zk@yahoo.com

10 Agricultural Botany Department, Faculty of Agriculture (Saba Basha), Alexandria University, Alexandria 21531,Egypt; ahmed_heflish@yahoo.com (A.A.H.); ibelsamra@hotmail.com (I.A.E.); said.behiry@alexu.edu.eg (S.I.B.)

* Correspondence: aabdelkhalek@srtacity.sci.eg; Tel.: +20-1007556883

\begin{abstract}
Three different concentrations of four (ethanol, acetone, methanol, and diethyl ether) extracts of licorice, doum, and banana peel were evaluated for antifungal and antimycotoxigenic efficiency against a maize aflatoxigenic fungus, Aspergillus flavus. Among them, the licorice diethyl ether $75 \%$ extract was intensely active, showing the best wet and dry weight inhibition and exhibiting the highest efficacy ratio (91\%). Regarding aflatoxin B1 (AFB1) production, all the plant extracts tested were effective against AFB1 production after one month of maize storage, with average efficacy ratios ranging from $74.1 \%$ to $97.5 \%$. At the same time, Thiram fungicide exhibited an efficacy ratio of $20.14 \%$. The relative expression levels of three structural genes (aflD, aflP, and aflQ) and two regulatory genes (aflR and aflS) were significantly downregulated when compared to untreated maize grains or Thiram-treated maize grains. The doum diethyl ether $75 \%$ peel extract showed the highest total phenolic content (60.48 mg GAE/g dry extract wt.) and antioxidant activity $(84.71 \mu \mathrm{g} / \mathrm{mL})$. GC-MS analysis revealed that dimethoxycinnamic acid, aspartic acid, valproic acid, and linoleic acid might imbue the extracts with antioxidant capacities in relation to fungal growth and aflatoxin biosynthesis. Finally, the results suggest that the three plant extracts can be considered a promising source for developing potentially effective and environmentally safer alternative ways to control aflatoxin formation, thus creating a potentially protective method for grain storage.
\end{abstract}

Keywords: plant extracts; Aspergillus flavus; maize; GC-MS; qRT-PCR 


\section{Introduction}

Aspergillus species produce different mycotoxins, i.e., aflatoxins B1, B2, G1, and G2 by Aspergillus flavus, A. parasiticus, A. nomius, and A. pseudotamarii; ochratoxin A by $A$. ochraceus; patulin by $A$. clavatus and $A$. terreus; and cyclopiazonic acid (CPA) by A. flavus and A. versicolor [1,2]. Currently, 18 types of aflatoxin produced by Aspergillus spp. have been identified; among these types, aflatoxin B1 (AFB1) is reported to be the most toxic injurious mycotoxin to mammals [3,4]. Seed fungi may cause losses in seed development, storage, or germination, especially aflatoxigenic fungi [5]. Contamination with aflatoxins mainly concerns dried fruit (nuts, peanuts, pistachio nuts, and dried figs), cereal grains (primarily maize and maize products), some spices, and oilseeds [6,7]. However, due to their high consumption, maize and groundnuts are primary sources for human exposure to aflatoxin worldwide [8].

AFB1 is one of the most frequently produced toxins, and it is regulated in different countries at a maximum tolerated level ranging from 4 to $20 \mathrm{ng} / \mathrm{g}$. Unfortunately, exposure to low doses of aflatoxins in humans leads to cancer induction, immune suppression, and stunted growth in young children [9]. As such, the control of aflatoxins in stored maize grains is a priority for mammal safety. Controlling aflatoxigenic A. flavus in grains and food during storage is regarded as a worldwide target for humans [10]. Synthetic antioxidants could be harmful, whereas plant extracts have great potential, as they are active, easy to prepare and apply, secured, and easy to biodegrade, as well as having a stimulating effect on plant metabolism [11,12]. Higher plants' natural products provide a new source of antimicrobial agents with a possible novel mechanism of action [13-15]. Tagne et al. [16] reported that Cymbopogon citratus, Occimum gratissimum, and Thymus vulgaris essential oils or plant powder extracts could be useful as potential substitutes to synthetic fungicides in controlling seed-borne fungi, including mycotoxigenic fungi-infected maize grains. The potential use of bioactive metabolites, such as natural antioxidants and phenolic compounds, affects growth and toxin production in primary mycotoxigenic fungi $[11,17]$. To meet the increasing demand in developed countries for safer foods and healthier manufacturing methods, several methods have been developed to remove mycotoxins from contaminated foods, including physical separation and adsorption. Agro-by-products such as peels and seed husks result in the formation of a high amount of waste materials $[18,19]$. However, the accumulation of wastes poses a problem to the environment, as they are prone to microbial spoilage [20]. Agro-waste may be a source of high-added value products that are potentially useful as beneficial food constituents, food flavors, antioxidants, cosmetics, chemopreventive agents, drugs, or drug adjuvants. Therefore, researchers have made efforts to explore the possibility of reusing plant wastes as a source of organics. Agro-wastes such as peels of various fruits and vegetables are used in food and other industries [21]. Globally, fruit peels are agricultural waste discarded as useless material; they cause waste management problems despite having some compost and cosmetic potential [22]. Fruit peels are known to contain many materials with biological activities and medicinal properties [23,24]. For example, tannins, alkaloids, flavonoids, phlobatannins, terpenoids, and glycosides are bioactive compounds that are usually available in the peel of banana, doum, and licorice. The peel extracts, which contain rutin, could have anticarcinogenic, antioxidant, and antimicrobial abilities [25-27]. In higher plants, linoleic acid is substrate for the production of a range of trihydroxy oxylipins [28], which are known to possess antifungal activity. Linolenic acid and allylphenol reduced mycelial growth of Rhizoctonia solani by $74 \%$ and Pythium ultimum by $65 \%$ at $1000 \mu \mathrm{M}$, and also reduced biomass production; they have been reported to be active against a number of plant pathogens $[29,30]$.

Various environmental conditions influence the AFB1 production pathway, one of the recognized secondary fungal metabolic pathways [31]. Thirty structural genes aid

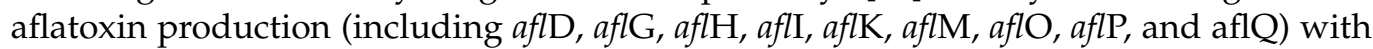
both regulatory genes aflR and aflS [31]. Several studies have discussed the role of many plant-derived compounds to degrade AFB1 or stop the expression of aflatoxin biosynthesis genes [31-33]. Liang et al. [34] reported that cinnamaldehyde at a concentration 
of $0.40 \mathrm{mM} / \mathrm{L}$ could suppress AFB1 synthesis and the expression of aflR, aflD, aflM, and aflP genes in A. flavus. Several studies carried out by Caceres et al. [35] and El Khoury et al. [36] showed the activity of different concentrations of aqueous hyssop extract, and the two terpenes piperine or eugenol, in relation to inhibiting the expression of 25 out of 27 genes in the AFB1-biosynthesis cluster. Therefore, this study evaluates the effectiveness of different extracts of licorice, doum, and banana peels in controlling aflatoxins produced on maize grains during storage and compares these results with those attained with Thiram fungicide. The GC-MS analysis was performed to ascertain the active components of peel extracts that reduced $A$. flavus growth and AFB1-biosynthesis.

\section{Materials and Methods}

\subsection{Fungal Isolation and Identification}

Different maize grain samples collected from local markets at Alexandria governorate, Egypt, were used as source material for fungal isolation. Twenty-six Aspergillus isolates were purified; morphologically characterized by determining the colony color, texture, spore color, size, conidiophore structure, and vesicle form [37,38]; and evaluated for their ability to produce AFB1 by measuring its concentration in culture filtrates by HPLC $[39,40]$. The fungal isolate that gave the highest production of AFB1 was molecularly identified via PCR amplification and sequencing of the ITS region, as described previously [41,42].

\subsection{Preparation of Extracts}

Peels from edible plants were used throughout this study, i.e., doum (Hyphaene thebaica), licorice (Glycyrrhiza glabra), and banana (Musa paradisiaca L.). Extraction was carried out according to Pinto et al. [43]. The collected plant peels were air-dried and then ground with a laboratory mill 3610 (PerkinElmer, Inc., Waltham, MA, USA). In total, $100 \mathrm{~mL}$ of the following solvents: (i) ethanol, (ii) diethyl ether, (iii) methanol, and (iv) acetone was added to $20 \mathrm{~g}$ of ground plant peels at different concentrations $(25 \%, 50 \%$, and $75 \%, v / v$ : solvent/water), kept for $24 \mathrm{~h}$ on Unimax 1010 platform shaker (Heidolph Instruments $\mathrm{GmbH} \& \mathrm{Co}$. KG, Schwabach, Germany) at $200 \mathrm{rpm}$, and filtered through Whatman paper (No.1). All the extracts were stored in the fridge until use.

\subsection{Determination of Total Phenol Contents of Extracts}

The total phenolics content (TPC) of each extract was determined by the FolinCiocalteau method, according to Turkmen et al. [44] and Farahmandfar et al. [45]. Briefly, $0.5 \mathrm{~mL}$ of the extract was mixed with $1 \mathrm{~mL}$ of water and $0.5 \mathrm{~mL}$ of $1 \mathrm{~mol} / \mathrm{L}$ Folin-Ciocalteau reagent (Sigma-Aldrich Chemie $\mathrm{GmbH}$, Taufkirchen, Germany). After $3 \mathrm{~min}, 1.5 \mathrm{~mL}$ of $10 \% \mathrm{Na}_{2} \mathrm{CO}_{3}$ was added, and then the mixture was incubated in a test tube at room temperature for $10 \mathrm{~min}$. The absorbance values of all samples were measured at $725 \mathrm{~nm}$ using a Spectrophotometer OPTIMA SP-300 (Itabashi, Tokyo, Japan). The TPC was expressed as milligrams of gallic acid (GAE) equivalents per gram (g) of the extract.

\subsection{Determination of Extracts' Antioxidant Activities}

Antioxidant activity (1,1-diphenyl-2-picrylhydrazyl (DPPH) assay) was measured by the radical scavenging ability of the DPPH radical. The free radical scavenging capacity of ethanolic and diethyl ether extracts was measured using the method described by Asnaashari et al. [46]. The results were calculated using the following equation: Radical scavenging capacity $\%=\left[\frac{\mathrm{AB}-\mathrm{AA}}{\mathrm{AB}}\right] \times 100$, where $\mathrm{AB}=$ absorption of blank sample and $\mathrm{AA}=$ absorption of sample solution.

\subsection{GC-MS Analysis}

The three plant extracts were analyzed for their components using a Trace GC UltraISQ mass spectrometer (Thermo Scientific, Waltham, MA, USA) with a direct capillary column TG-5MS (30 m $\times 0.25 \mathrm{~mm} \times 0.25 \mu \mathrm{m}$ film thickness). Program conditions and sampling were performed as published previously [47]. The constituents were identified on 
the basis of the Wiley and NIST MS library database and compared mass spectra literature data and retention time $[48,49]$.

\subsection{Effect of Plant Extracts on A. flavus Growth and AFB1 Production}

\subsubsection{Dry and Wet Weight Estimations}

First, a plate with $15 \mathrm{~mL}$ potato dextrose agar (PDA) was inoculated with A. flavus Af1 isolate and incubated at $30{ }^{\circ} \mathrm{C}$ for 7 days. Plugs of $5 \mathrm{~mm}$ in diameter were cut from A. flavus Af1 PDA culture and used to inoculate a $50 \mathrm{~mL}$ of yeast extract sucrose (YES) broth (one disk for each flask) prepared in conical flasks. At three different concentrations, $1 \mathrm{~mL}$ of each extract $(25 \%, 50 \%, 75 \%)$ was added to YES broth pre-inoculated with $A$. flavus Af1 plugs then incubated at $30{ }^{\circ} \mathrm{C}$ for 15 days. After the incubation period, the fungal mat of each treatment was collected and dried in the oven at $50{ }^{\circ} \mathrm{C}$ for four days. The fungal mat wet and dry weights were recorded in all treatments. YES broth culture filtrates in all treatments were used to extract AFB1; briefly, $2 \mathrm{~mL}$ of the fungal culture broth was mixed and vortexed with an equal volume of chloroform in a $15 \mathrm{~mL}$ tube. The mixture was then centrifuged for $5 \mathrm{~min}$ at $10,528 \times g$, and $2 \mathrm{~mL}$ of the lower layer was transferred to a new glass vial. The chloroform extracts were evaporated under a gentle stream of air, and the dried extracts were reconstituted with $1 \mathrm{~mL}$ methanol [39]. All the prepared samples were filtered into HPLC vials through a $0.2 \mu \mathrm{m}$ syringe filter (Sigma-Aldrich Chemie GmbH, Taufkirchen, Germany) before HPLC analysis.

Efficacy ratios (ER) for aflatoxin inhibition were estimated according to the following equation [40]:

$$
(\mathrm{ER}) \%=\left[\frac{\text { Aflatoxin conc. in control- Aflatoxin conc. in treatment }}{\text { Aflatoxin conc. in control }}\right] \times 100
$$

\subsubsection{Effect of Plant Extracts on Maize Storage}

In total, $50 \mathrm{~g}$ of surface-sterilized maize grains were placed in sterile glass jars and treated with the best effective plant extracts inhibiting AFB1 production in YES broth, as resulted in the experiment indicated in Section 2.6.1. In the maize storage experiment, the Thiram fungicide (Bayer Crop Science LP, The Research Triangle Park, NC, USA) treatment served as a positive control. After that, each glass jar was inoculated with a $5 \mathrm{~mm}$ disk of $A$. flavus and incubated at $30{ }^{\circ} \mathrm{C}$ for 30 days. After the end of the storage period, the characteristics of maize grains, i.e., grain shape and odor, were recorded according to the scale mentioned in Table 1. All the tested grains were ground to extract AFB1 according to Hoeltz et al. [50], with some modifications; $20 \mathrm{~g}$ of contaminated milled maize grains were mixed with $100 \mathrm{~mL}$ of $\mathrm{MeOH}$ and $12 \mathrm{~mL} \mathrm{4 \%} \mathrm{KCl}(w / v)$. The samples were centrifuged for $2 \mathrm{~min}$ at $10,528 \times g$ and filtered. After that, $100 \mathrm{~mL}$ of $10 \%(w / v) \mathrm{CuSO}_{4}$ was added to the filtrate, stirred, and filtered. Then, an equal volume of distilled water was added to the filtrate in the separation funnel, and AFB1 was extracted twice with $15 \mathrm{~mL}$ chloroform. The solvent extracts were collected and evaporated in a water bath at $60{ }^{\circ} \mathrm{C}$. Finally, the samples were inputted into HPLC vials for analysis.

Table 1. Scale for maize grain approval based on the change in shape and odor.

\begin{tabular}{cccc}
\hline Grain Shape Change & Odor Change & Approval & Scale \\
\hline Whole grains (no change in shape) & No smell & Most approved & 5 \\
Mild simple & Mild simple & Highly approved & 4 \\
Moderate & Moderate & Very approved & 3 \\
Great & Great & Approved & 2 \\
Very great & Pungent & Unapproved & 1 \\
\hline
\end{tabular}

\subsubsection{HPLC Analysis of AFB1}

The AFB1 standard was prepared by dissolving $2.5 \mathrm{mg}$ of AFB1 (Sigma-Aldrich, Saint Louis, MO, USA) in $100 \mathrm{~mL}$ of toluene-acetonitrile $(9: 1, v / v)$ solution, leading to a final 
concentration of $25 \mathrm{ng} / \mathrm{mL}$. AFB1 stock solution $(100 \mathrm{~mL})$ was divided into $1 \mathrm{~mL}$ vials and nitrogen dried. To obtain a concentration of $25 \mathrm{ng} / \mathrm{mL}, 1 \mathrm{~mL}$ of methanol was added to each vial. The calibration measurements of AFB1 standard solutions at concentrations of $5,2,1,0.5,0.2$, and $0 \mathrm{ppb}$ were prepared with a solution containing $7 \%$ methanol, $92 \%$ 0.01 phosphate-buffered saline, and 1\% dimethylformamide [51]. For AFB1, the limit of detection is $0.01 \mathrm{ppb}$ and the limit of quantification is $1 \mathrm{ppb}$. AFB1 assay was carried out using Agilent 1260 Infinity HPLC Series (Agilent, Santa Clara, CA, USA) according to HPLC conditions, i.e., analytical column: Zorbax Eclipse XDB-C18, $4.6 \mathrm{~mm} \times 150 \mathrm{~mm}, 3.5 \mu \mathrm{m}$; mobile phase: water $/ \mathrm{MeOH} / \mathrm{ACN} ; 50 / 40 / 10(v / v / v)$; flow rate: $0.8 \mathrm{~mL} / \mathrm{min}$; temperature: ambient; detector: UV $365 \mathrm{~nm}$; and injection volume: $10 \mu \mathrm{L}(0.044 \mathrm{mg} / \mathrm{mL})$ [39].

\subsubsection{Real-Time PCR Assay}

Total plant RNA isolation was performed using the guanidium isothiocyanate method, with some modifications described previously [52]. Both concentration and purity of the extracted RNA were estimated on Nano SPECTROstar (BMG Labtech, Ortenberg, Germany) system. At the same time, the agarose gel electrophoresis was used to ascertain the integrity of RNA. For cDNA synthesis, $2 \mu \mathrm{g}$ of DNase-treated total RNA of each sample was used as a template in the reverse transcription reaction, which was performed as described previously $[53,54]$. The real-time PCRs were performed in a Qiagen RGQ Rotor-Gene $Q$ 2-Plex HRM real-time PCR system (Qiagen, Hilden, Germany). The primers used in this study, illustrated in Table 2, targeted the aflatoxin biosynthetic pathway. The $\beta$-tubulin transcript was used as an internal reference housekeeping gene to normalize the amount of total RNA of each reaction. The qPCR reactions were performed in a total volume of $20 \mu \mathrm{L}$ using SYBR Green PCR Master Mix, as previously described [55,56]. The relative gene expression levels were calculated from the threshold cycle according to the $2^{-\Delta \Delta C_{T}}$ method [57].

Table 2. The list of primers and the corresponding clustered aflatoxin biosynthesis pathway genes showing enzymes involved and their functions in the study.

\begin{tabular}{|c|c|c|c|}
\hline Target Gene & Sequences $\left(5^{\prime}-3^{\prime}\right)$ & Function in the Biosynthetic Pathway & Target Size (bp) \\
\hline$\beta$-Tubulin (benA) & $\begin{array}{l}\text { Forward: CTTGTTGACCAGGTTGTGGAT } \\
\text { Reverse: GTCGCAGCCCTCAGCCT }\end{array}$ & Reference housekeeping gene & 51 \\
\hline aflD (nor-1) & $\begin{array}{l}\text { Forward: GTCCAAGCAACAGGCCAAGT } \\
\text { Reverse: TCGTGCATGTTGGTGATGGT }\end{array}$ & $\begin{array}{c}\text { Norsolorinic acid (NOR) } \rightarrow \text { averantin } \\
(\mathrm{AVN})\end{array}$ & 66 \\
\hline $\operatorname{afl} \mathrm{P}($ omt $\mathrm{A})$ & $\begin{array}{l}\text { Forward: GGCCGCCGCTTTGATCTAGG } \\
\text { Reverse: ACCACGACCGCCGCC }\end{array}$ & $\begin{array}{c}\text { Sterigmatocystin (ST) } \rightarrow \\
\text { O-methylsterigmatocystin (OMST) }\end{array}$ & 123 \\
\hline $\operatorname{afl} \mathrm{Q}(\operatorname{ord} \mathrm{A})$ & $\begin{array}{l}\text { Forward: GTGTCCGCAGTGTCTAGCTT } \\
\text { Reverse: GCTCAAAGGTCGCCAGAGTA }\end{array}$ & $\begin{array}{l}\text { O-methylsterigmatocystin (OMST) } \\
\text { aflatoxin B1(AFB1) }\end{array}$ & 115 \\
\hline aflR & $\begin{array}{l}\text { Forward: CTCAAGGTGCTGGCATGGTA } \\
\text { Reverse: CAGCTGCCACTGTTGGTTTC }\end{array}$ & Pathway regulator & 86 \\
\hline aflS & $\begin{array}{l}\text { Forward: CTGCAGCTATATTGCCCACA } \\
\text { Reverse: TAAACCCAGGCAGAGTTGGT }\end{array}$ & Pathway regulator & 117 \\
\hline
\end{tabular}

\subsection{Statistical Analysis}

The experiment was a completely randomized design [58]. Treatment means were compared by Duncan's multiple range test [59]. All statistical analysis was performed using the analysis of variance technique using CoStat program version 6.303 (CoHort software, Monterey, CA, USA). For the expression analysis of aflatoxin biosynthesis genes, the data were expressed as means \pm S.E. Values were considered statistically significant when $p \leq 0.05$.

\section{Results and Discussion}

\subsection{The Ability of Aspergillus Isolate to Produce Aflatoxin and Identification}

The aflatoxigenic fungal isolate $A$. flavus was used in this study as a high AFB1 producer with $26.79 \mathrm{ppb}$. A. flavus morphological characteristics were performed as described 
by Klich [38], where the fungal colonies were olive-green, velvety flat with a raised texture, forming dark-brown sclerotia. The conidiophores were colorless, rough, and thick-walled, bearing vesicles globose to sub-globose with radiated sterigmata and globose, thin-walled, slightly rough conidia ranging from 250 to $450 \mu \mathrm{m}$. Using the procedure described by Al-Huqail et al. [60], the ITS sequence result identified the isolate as A. flavus, and the sequence was deposited in the GenBank database under accession no. (\#MG202161).

\subsection{Effect of the Applied Plant Extracts on A. flavus Growth and AFB1 Production}

The licorice, doum, and banana plant peels were extracted with different solvents, i.e., ethanol, acetone, methanol, and diethyl ether, at concentrations of 25, 50, and 75\%, to study their effect on A. flavus growth (dry and wet weight) and AFB1 production (Table 3). The obtained results revealed that the smallest significantly wet and dry weight values were obtained by application of doum-ethanol 25\% (0.19 and $0.06 \mathrm{~g}$, respectively), licorice-acetone $75 \%$ (0.08 and $0.02 \mathrm{~g}$, respectively), and banana-acetone $50 \%$ (0.30 and $0.02 \mathrm{~g}$, respectively) compared with control (7.74 and $1.72 \mathrm{~g}$, respectively). Our results reported the antifungal ability of licorice peel extract, which is consistent with findings of previous studies. Hojo and Sato [61] found that licorice extracts with $80 \%$ methanol (oil-based extract of licorice) have significant fungicidal effects against Arthrinium sacchari M001 and Chaetomium funicola M002. Moreover, Mohseni [62] demonstrated less mycelial growth (about 100×) in the presence of licorice extract after $72 \mathrm{~h}$ of incubation in Aspergillus parasiticus. In our study, banana peel ethanolic extract results were somewhat similar to El Zawawy [63], who found that the $2 \%$ banana peel ethanolic extract had moderate antifungal activity against $A$. flavus and had the best inhibitory effect against $A$. niger and Alternaria alternata at $10 \%$ concentration using the agar well diffusion method [64]. Meanwhile, Behiry et al. [65] found that the methanolic extract from banana peels at concentrations of 1, 2, and 3\% inhibited the mycelial growth of Fusarium culmorum and Rhizoctonia solani fungi. Even though all concentrations of methanolic doum extract had slight antifungal properties, Taha et al. [66] and Abdallah [67] reported that the doum methanolic extract exhibited no antifungal activity against $A$. flavus and $A$. niger ATCC 6275. It has been reported that the existence of alkaloids, tannins, phenolics, cardiac glycosides, saponin, and flavonoids in different fruit peel extracts has been correlated with antifungal activity $[63,68]$.

Table 3. Effect of the applied plant extracts on the wet and dry weight of A. flavus mat and the efficacy ratio of AFB1 production inhibition (ER\%).

\begin{tabular}{|c|c|c|c|c|c|c|c|c|c|c|}
\hline \multirow{3}{*}{ Solvent } & \multirow{3}{*}{ Concentration (\%) } & \multicolumn{9}{|c|}{ A Wet and Dry Weight of A. flavus (g) } \\
\hline & & \multicolumn{3}{|c|}{ Doum } & \multicolumn{3}{|c|}{ Licorice } & \multicolumn{3}{|c|}{ Banana } \\
\hline & & Wet & Dry & ER\% & Wet & Dry & ER\% & Wet & Dry & ER\% \\
\hline \multirow{3}{*}{ Ethanol } & 25 & $0.19 \mathrm{k}$ & $0.06 \mathrm{~m}$ & $85.96 \mathrm{~b}$ & $3.53 \mathrm{~h}$ & $0.81 \mathrm{f}$ & $50.56 \mathrm{k}$ & $2.83 \mathrm{~d}$ & $0.29 \mathrm{e}$ & $85.65 \mathrm{a}$ \\
\hline & 50 & $5.13 \mathrm{de}$ & $0.83 \mathrm{~g}$ & $62.17 \mathrm{~h}$ & $0.23 \mathrm{k}$ & $0.06 \mathrm{k}$ & $64.68 \mathrm{f}$ & $1.36 \mathrm{~g}$ & $0.21 \mathrm{f}$ & $73.52 \mathrm{f}$ \\
\hline & 75 & $1.30 \mathrm{j}$ & 0.231 & $61.87 \mathrm{i}$ & $3.04 \mathrm{j}$ & $0.77 \mathrm{~g}$ & $68.13 \mathrm{e}$ & $1.32 \mathrm{~h}$ & $0.20 \mathrm{f}$ & $77.35 \mathrm{~d}$ \\
\hline \multirow{3}{*}{ Acetone } & 25 & $5.06 \mathrm{f}$ & $0.98 \mathrm{c}$ & $71.61 \mathrm{f}$ & 0.151 & 0.041 & $59.14 \mathrm{~g}$ & $0.45 \mathrm{k}$ & $0.05 \mathrm{i}$ & $69.74 \mathrm{i}$ \\
\hline & 50 & $5.17 \mathrm{~d}$ & $0.81 \mathrm{~h}$ & $64.30 \mathrm{~g}$ & $6.42 \mathrm{~b}$ & $0.84 \mathrm{e}$ & $69.28 \mathrm{~d}$ & $0.30 \mathrm{~m}$ & $0.02 \mathrm{j}$ & $79.39 \mathrm{c}$ \\
\hline & 75 & $5.65 c$ & $0.89 \mathrm{e}$ & $44.65 \mathrm{k}$ & $0.08 \mathrm{~m}$ & $0.02 \mathrm{~m}$ & 45.031 & $1.41 \mathrm{f}$ & $0.14 \mathrm{~g}$ & $85.08 \mathrm{~b}$ \\
\hline \multirow{3}{*}{ Methanol } & 25 & $4.32 \mathrm{~g}$ & $0.59 \mathrm{i}$ & $46.37 j$ & $6.23 c$ & $0.96 \mathrm{c}$ & $56.61 \mathrm{~h}$ & $3.68 c$ & $0.42 \mathrm{c}$ & $49.15 \mathrm{j}$ \\
\hline & 50 & $7.36 \mathrm{~b}$ & $1.03 b$ & $83.04 \mathrm{c}$ & $6.11 \mathrm{~d}$ & $1.01 \mathrm{~b}$ & $52.68 \mathrm{j}$ & $1.17 \mathrm{i}$ & $0.07 \mathrm{~h}$ & 34.381 \\
\hline & 75 & $5.15 \mathrm{de}$ & $0.93 \mathrm{~d}$ & 40.611 & $5.72 \mathrm{e}$ & $0.89 \mathrm{~d}$ & $56.01 \mathrm{i}$ & $4.59 \mathrm{~b}$ & $0.47 \mathrm{~b}$ & $39.24 \mathrm{k}$ \\
\hline \multirow{3}{*}{$\begin{array}{c}\text { Diethyl } \\
\text { ether }\end{array}$} & 25 & $3.75 \mathrm{~h}$ & $0.26 \mathrm{k}$ & $76.32 \mathrm{~d}$ & $4.46 \mathrm{~g}$ & $0.66 \mathrm{i}$ & $74.68 \mathrm{c}$ & $2.82 \mathrm{e}$ & $0.38 \mathrm{~d}$ & $70.86 \mathrm{~g}$ \\
\hline & 50 & $5.09 \mathrm{ef}$ & $0.27 \mathrm{j}$ & $71.94 \mathrm{e}$ & $5.02 \mathrm{f}$ & $0.70 \mathrm{~h}$ & $88.38 \mathrm{~b}$ & 0.431 & $0.02 \mathrm{j}$ & $70.85 \mathrm{~h}$ \\
\hline & 75 & $3.60 \mathrm{i}$ & $0.86 \mathrm{f}$ & $86.86 \mathrm{a}$ & $3.44 \mathrm{i}$ & $0.41 \mathrm{j}$ & $91.43 \mathrm{a}$ & $0.75 \mathrm{~b}$ & $0.05 \mathrm{i}$ & $77.08 \mathrm{e}$ \\
\hline Control & & $7.74 \mathrm{a}$ & $1.72 \mathrm{a}$ & $0 \mathrm{~m}$ & $7.74 \mathrm{a}$ & $1.72 \mathrm{a}$ & $0 \mathrm{~m}$ & $7.74 \mathrm{a}$ & $1.72 \mathrm{a}$ & $0 \mathrm{~m}$ \\
\hline
\end{tabular}

Means followed with the same letter (s) in the same column are not significantly different from each other at $p \leq 0.05$. 
Furthermore, most of the tested solvents at different concentrations were highly effective against AFB1 production. Efficiency ratios of AFB1 inhibition (ER\%) values ranged from 34 to $91 \%$. However, methanolic extracts were the least effective against AFB1 production, where ER\% values ranged between 34.38 and $40.6 \%$ in the different extracts.

The ER\% values, shown in Table 3, indicated promising results for banana peel extracts with $25 \%$ ethanolic extract and $75 \%$ acetone extract $(85.65 \%$ and $85.08 \%$, respectively), whereas the smallest ER\% values were obtained by $50 \%$ and $75 \%$ methanolic extracts from banana peel (34.38\% and 39.24\%, respectively). Doum extract data explained in Table 3 showed significant differences among ER\% values of the tested solvent concentrations. The highest ER\% was attained at 75\% diethyl ether treatment, with $86.86 \%$ compared to ER\% values of the other solvents. However, the least effective ratio was detected in methanol and acetone at a $75 \%$ concentration ( 40.61 and $44.65 \%$, respectively). On the other hand, Table 3 shows significant differences among ER\% values of the tested solvent concentrations in licorice extract treatments. Treatment with diethyl ether at concentrations of $75 \%$ and $50 \%$ resulted in the highest AFB1 inhibition values (91.43\% and $88.38 \%$, respectively). However, the smallest ER\% values were detected in the 75\% acetone treatment $(45.03 \%)$.

Our results concerning fungal growth and AFB1 inhibitions can be explained by the findings of Borges et al. [69]. They reported that the mode of action of these plant extract antioxidants suppresses aflatoxins by neutralizing and scavenging free radicals and inhibiting their chains of propagation, rendering them into less toxic molecules. Furthermore, solvents differed in their efficiency according to their concentrations and a given plant's components. Naik et al. [70] and Bernardo and Sagum [71] reported that ethanolic and methanolic extracts of Solanum melongena L. (eggplant) and sugar apple peels (Annona squamosa) had high free radical scavenging activities against human pathogens; these results support our findings. On the other hand, Adom et al. [72] and Laddomada et al. [73] mentioned that phenolic acids cross-linked with the polymers' plant cell wall, such as wheat bran components, are considered the most important antioxidants.

\subsection{Corn Storage Experiment}

\subsubsection{Effect of Applied Extracts on AFB1 Production}

The results presented in Table 4 indicate that 75\% diethyl ether licorice peel extract was the best treatment, and it showed the lowest value of AFB1 (9.65 ppb), with an ER of $97.75 \%$; this was followed by $75 \%$ diethyl ether doum peel extract $(66.21 \mathrm{ppb})$. At the same time, the value of AFB1 in 25\% ethanolic banana peel extract was $110.48 \mathrm{ppb}$ compared to the other treatments. This finding is consistent with that of Mohseni et al. [62], who demonstrated that aflatoxin production decreased in A. parasiticus in the presence of $50 \%$ licorice extract.

Table 4. Effect of plant extracts on AFB1 production in stored inoculated maize grains with A. flavus.

\begin{tabular}{cccc}
\hline Treatments & Solvent Concentration & AFB1 (ppb) & ER\% \\
\hline Healthy moistened control & - & 0.00 & - \\
Infected control & - & 425 & 84.42 \\
Doum & Di ethyl ether 75\% & 66.21 & 97.75 \\
Licorice & Di ethyl ether 75\% & 9.56 & 74.12 \\
Banana & Ethanol 25\% & 110.48 & 20.15 \\
Thiram & $2.5 \mathrm{mg} / \mathrm{mL}$ & 339.37 & 5.60 \\
\hline LSD 0.05 & & 5 & \\
\hline
\end{tabular}

\subsubsection{Effect of Applied Plant Extracts on Grain Appearance}

Table 5 and Figure 1 indicate that grains' appearance changed significantly for the tested plant extracts and fungicide compared to control. Doum peel extract has excellent antifungal activity and a good grain appearance (i.e., low or no visible mold or grain defect on grain) compared to other treatments and is followed by licorice extract and banana peel extract. Treatment of inoculated grains with Thiram fungicide at the recommended 
concentrations resulted in rotting, shape deformity, bad odors, and unapproved grains. Our results agree with Gemeda et al. [74] and El-Aziz et al. [75]. They recorded similar Aspergillus fungal dry weight reductions due to treatment with essential oils. Such decreases were also reported in licorice extract [76]. The obtained results also matched with Yazdani et al. [77], who showed that certain phenolic compounds could decline aflatoxin production in A. flavus.

Table 5. Effect of the tested extracts and fungicide on grain appearance and smell.

\begin{tabular}{ccccc}
\hline Treatments & Solvent Concentration & Grain Shape & Smell & Scale \\
\hline Healthy moistened control & - & 5 & 0 & 5 \\
\hline Infected control & - & 0 & 5 & 0 \\
\hline Doum & Di ethyl ether $75 \%$ & 5 & 1 & 4 \\
\hline Licorice & Di ethyl ether $75 \%$ & 4 & 1 & 4 \\
\hline Banana & Ethanol $25 \%$ & 4 & 1 & 4 \\
\hline Thiram & $2.5 \mathrm{mg} / \mathrm{mL}$ & 0 & 5 & 0 \\
\hline
\end{tabular}
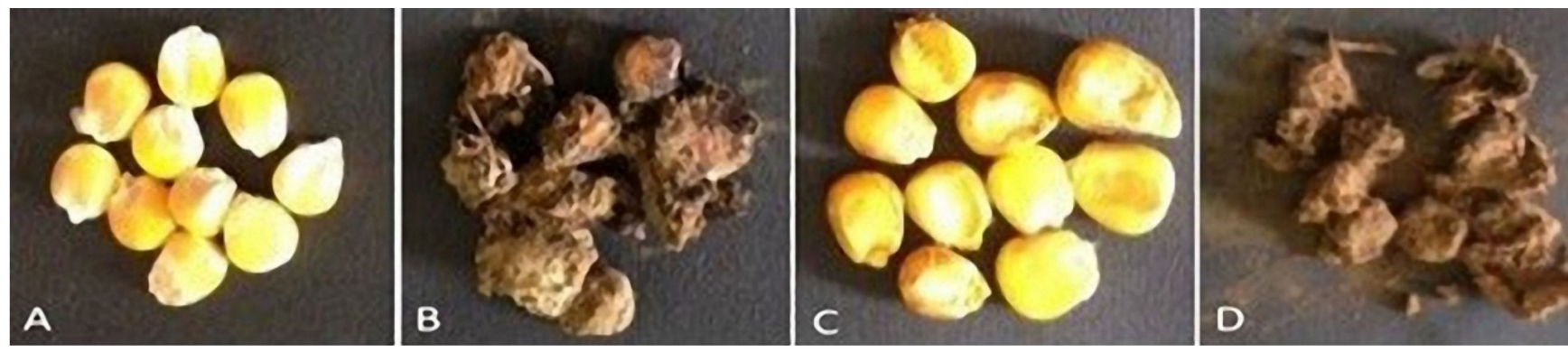

Figure 1. Effects of the plant extracts and Thiram fungicide on the appearance of inoculated maize grains after one month of storage: (A) healthy moistened control, (B) infected control inoculated with A. flavus, (C) inoculated maize grains treated with any of the tested extracts, (D) inoculated maize grains treated with Thiram fungicide.

\subsection{Expression of AFB1 Biosynthesis Genes Using qRT-PCR}

Aflatoxin biosynthesis, especially AFB1, is a complex enzymatic pathway [78]. In A. flavus, AFB1 is produced from acetyl CoA via about 25 genes that reside in a $75 \mathrm{~kb}$ cluster encoding more than 18 enzymatic stages $[79,80]$. Such pathways are organized by diverse regulatory and structural genes [81]. In the current study, we examined the effect of the three-plant extracts, as well as Thiram fungicide, on the relative expression of three structural genes (aflD, aflP, and aflQ) and two regulatory genes (aflR and aflS) (Figure 2). The aflD plays an essential role in the early conversion of norsolorinic acid to averantin. At the same time, aflP and aflQ genes encoded enzymes necessary for converting sterigmatocystin to o-methylsterigmatocystin and AFB1 in the late steps of the aflatoxin pathway $[82,83]$. The highest relative transcription of $a f l D$ (6.643-fold) was seen in untreated maize grains (infected control), followed by Thiram treatment with a relative expression level 2.28-fold higher. On the other hand, the 75\% three-diethyl ether licorice peel extract, 75\% diethyl ether doum peel extract, and 50\% ethanolic banana peel extract treatments exhibited decreasing aflD expression, with relative expression levels of 1.664-, 1.201-, and 1.174-fold, respectively (Figure 2). Similarly, infected control treatment exhibited the greatest aflP and aflQ relative expressions that were 4.863- and 7.738-fold higher. On the other hand, the $75 \%$ diethyl ether licorice peel extract treatment showed the lowest transcriptional levels, with relative expression levels of 0.831 and 2.501 for aflP and aflQ, respectively (Figure 2). It was reported that the transcription of aflatoxin biosynthesis genes corresponded to the biosynthesis profile of AFB1 [80,84,85]. Lappa et al. [80] showed that the downregulation of aflM and aflP positively affected AFB1 formation. Moreover, Verheecke et al. [85] observed 
that the repression of aflM expression was also correlated with AFB1 content. Thus, the expression levels of biosynthetic aflatoxin pathway genes can be used as a marker of the aflatoxigenic content [84]. The results are in agreement with those of Mayer et al. [86], who observed that aflD expression levels in wheat artificially inoculated with an AF-producing A. flavus isolate are associated with growth kinetics of the fungus and AFB1 production. Thus, the expression of aflD, aflQ, and aflP genes can provide useful differentiation between aflatoxigenic and non-aflatoxigenic strains of $A$. flavus [84,87]. The aflR and aflS are key regulatory genes in the production of aflatoxin B1. Sweeney et al. [88] reported a significant correlation between aflatoxin production and the expression of aflR, as determined by qPCR. In the present study, the relative expression levels of two genes, aflR, and aflS, were downregulated in all treated grains compared to untreated controls (Figure 2). Degola et al. [89] showed that the expression of aflS and aflD could also be utilized to differentiate AFB1-producing from non-producing Aspergillus strains. Mohseni [62] reported that the relative expression of the aflR gene fell significantly by 1.5 times in comparison to its expression in fungus without licorice extract treatment. The obtained data indicate that the applied extract has an inhibitory effect on growth and aflatoxin production in A. parasiticus.

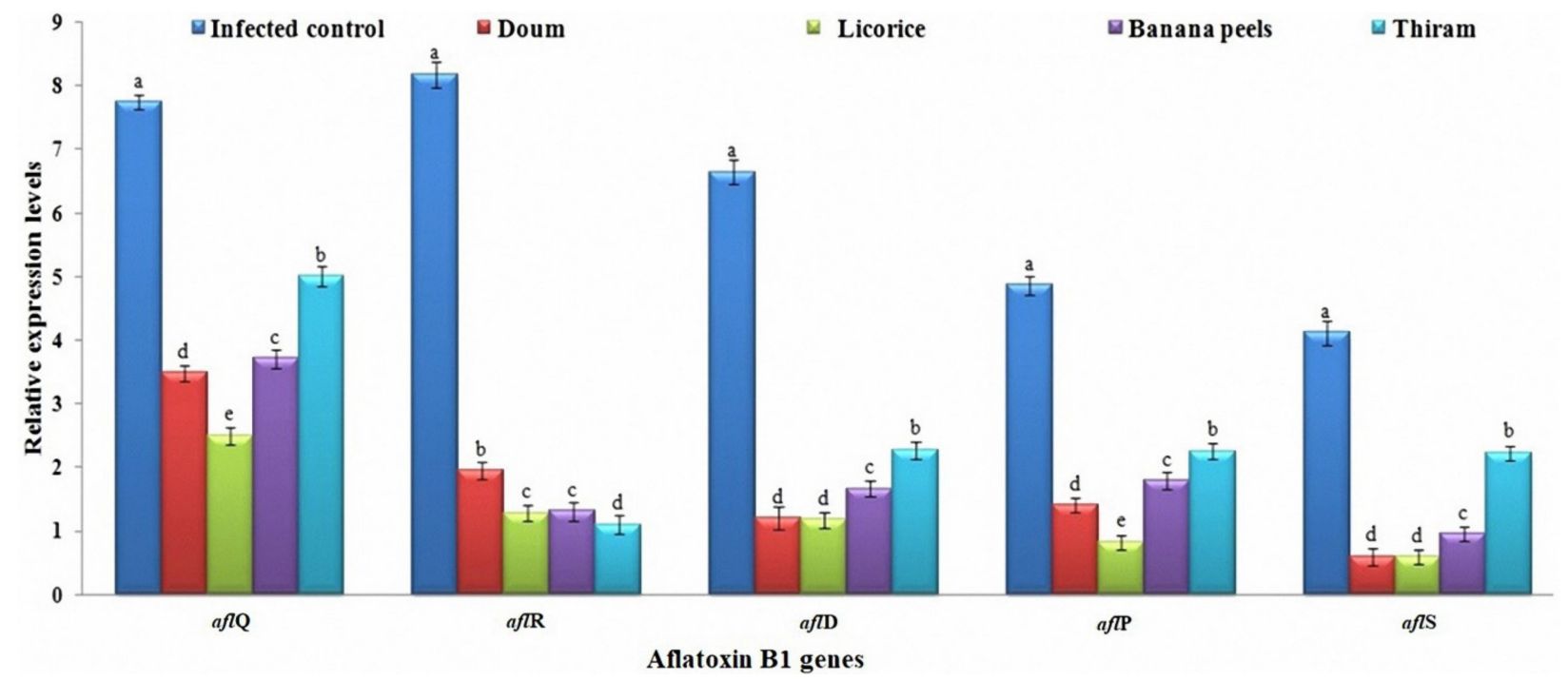

Figure 2. The relative expression levels of structural (aflD, aflP, and aflQ) and regulatory genes (aflR and aflS) of the aflatoxin B1 (AFB1) biosynthetic pathway in maize grains treated with doum, licorice, banana peel extracts, and Thiram fungicide before the Aspergillus flavus Af1 inoculation. Columns with the same letters among each gene are not significantly different at $p \leq 0.05$.

\subsection{Total Phenolic Content (TPC) of the Tested Plant Extracts}

The TPC of the tested plant materials was determined as mg GAE/g of dry extract weight. The obtained results showed that all the tested plant materials possessed high TPC that ranged from 18.83 to $60.48 \mathrm{mg}$ of GAE/g dry extract (Table 6). The highest TPC content was recorded in $75 \%$ diethyl ether doum peel extract $(60.48 \mathrm{mg}$ of GAE/g dry extract wt.). The lowest TPC value was detected in 75\% diethyl ether licorice peel extract (18.53 mg of GAE/g dry extract wt.). Thus, as reported before, phenolics are the most abundant secondary metabolites in plants, and they have drawn increasing attention due to their potent antioxidant properties and their marked effects in the prevention of various oxidative stress-associated diseases [90]. 
Table 6. Total phenolic contents (TPC) and antioxidant activity (AA) of the tested plants.

\begin{tabular}{cccc}
\hline Plant Extract & Solvent Concentration & $\begin{array}{c}\text { TPC }(\mathbf{m g G A E} / \mathbf{g} \text { Dry } \\
\text { Extract wt) } \pm \text { SD }\end{array}$ & AA $(\boldsymbol{\mu g} / \mathbf{m L})$ \\
\hline Ascorbic acid & - & - & 4.28 \\
Doum & Diethyl ether 75\% & $60.48 \pm 0.74$ & 84.71 \\
Licorice & Diethyl ether 75\% & $18.83 \pm 1.55$ & 67.53 \\
Banana & Ethanol 25\% & $37.28 \pm 0.64$ & 84.26 \\
\hline
\end{tabular}

\subsection{Antioxidant Activities of the Tested Plant Materials}

DPPH is a method used to test the ability of compounds to act as free radical scavengers or hydrogen donors and to evaluate the antioxidant capacity of extracts [91]. Antioxidant activities (AA) were determined in all the tested plant parts for DPPH scavenging $\mathrm{IC}_{50}(\mu \mathrm{g} / \mathrm{mL})$ values. According to the obtained results (Table 6), most tested plant materials showed relatively high antioxidative activity values. The doum extract exhibited the highest value of AA $(84.71 \mu \mathrm{g} / \mathrm{mL})$, while banana peels and licorice peels showed 84.26 and $67.53 \mu \mathrm{g} / \mathrm{mL}$, respectively. The results coincided with Hsu et al. [92] and Satish et al. [93], who noted that doum fruit showed considerable inhibitory activity against different Aspergillus species isolated from corn mine will. In the meantime, banana peel extract was proven to be a potent scavenger of free radicals and an excellent inhibitor of lipid peroxidation [94,95].

\subsection{Phytocompounds Identified in the Extracts of Doum, Licorice, and Banana Peels by GC-MS}

The results of GC-MS analysis of the doum, licorice, and banana peel extracts led to the identification of several bioactive compounds in each extract. The various extract components with different retention times (RT) are investigated in Table 7. A set of 27 compounds was identified in the doum peel extract; results revealed high relative abundance content of various compounds such as linoleic acid (16.49\%), 3,5 dihydroxy phenol (10.66\%), and 2,5-dimethyl-para-anisaldehyde (10.41\%). At an RT of $15.672 \mathrm{~min}$, the relative abundance of octadecanoic acid was $9.51 \%$; this is the esterification product of linoleic acid that acts as a signaling molecule.

Table 7. Phytocomponents identified in the extracts of doum, licorice, and banana peels by GC-MS.

\begin{tabular}{|c|c|c|c|c|c|}
\hline Peak No. & Retention Time & Compound Name & Doum \% & Licorice $\%$ & Banana $\%$ \\
\hline 1 & 6.246 & 2,5-Dimethyl-para-anisalehyde & 10.41 & - & - \\
\hline 2 & 9.85 & 2,6-Dihydroxycineol & 9.82 & - & - \\
\hline 3 & 7.03 & 3,5-Dimethoxycinnamic acid & - & 26.37 & - \\
\hline 4 & 8.4 & 6-Hydroxyflavone & - & 1.82 & 0.59 \\
\hline 5 & 15.547 & $3^{\prime}, 4^{\prime}, 7$-Trimethylquercetin & 1.06 & - & - \\
\hline 6 & 10.599 & 3,5,7-Tri-O-methylgalangin & - & - & 0.58 \\
\hline 7 & 10.19 & 3,5-Dihydroxyphenol & 10.66 & - & - \\
\hline 8 & 6.2 & 4- Methylcatechol & - & - & 4.54 \\
\hline 9 & 6.683 & 4-Ethylbenzaldehye & 4.01 & - & - \\
\hline 10 & 17.114 & 1,16-Hexadecanedioic acid & - & 2 & - \\
\hline 11 & 17.044 & $5 \beta, 7 \beta H, 10 \alpha$-Eudesm-11-en- $1 \alpha$-ol & 2.31 & 0.6 & 0.49 \\
\hline 12 & 8.4 & 6-Hydroxyflavone & 1.65 & - & - \\
\hline 13 & 6.62 & 7,8-Dihydro- $\alpha$-ionone & 1.3 & - & 1.7 \\
\hline 14 & 18.48 & n-Docosane & - & 1.47 & - \\
\hline 15 & 23.5 & Cannabinol & - & 0.9 & - \\
\hline 16 & 5.589 & Cedrol & - & - & 0.82 \\
\hline 17 & 9.716 & d-Mannose & 2.46 & - & 0.14 \\
\hline 18 & 4.988 & Deoxyribose & - & - & 7.14 \\
\hline 19 & 6.884 & Dimethoxyurene & 0.54 & - & - \\
\hline 20 & 19.68 & DL-Malic acid & - & 1.7 & - \\
\hline 21 & 22.337 & Estriol 16 $\alpha$-( $\beta$-D-glucuronide $)$ & - & 1.23 & - \\
\hline 22 & 5.391 & Ethylnorbornane & 7.03 & - & 0.97 \\
\hline
\end{tabular}


Table 7. Cont.

\begin{tabular}{|c|c|c|c|c|c|}
\hline Peak No. & Retention Time & Compound Name & Doum \% & Licorice \% & Banana \% \\
\hline 23 & 7.428 & Farnesol & 2.15 & - & 3.23 \\
\hline 24 & 21.146 & Squalane & - & 1.16 & - \\
\hline 25 & 15.852 & Glycitein & 1.22 & 1.45 & 1.85 \\
\hline 26 & 7.776 & Hexestrol & 0.8 & - & 0.75 \\
\hline 27 & 15.107 & 4-Hydroxy-2-methoxybenzaldehyde & - & - & 0.76 \\
\hline 28 & 3.88 & L-Aspartic acid & - & 11.28 & - \\
\hline 29 & 7.016 & Ledol & 1.22 & - & - \\
\hline 30 & 8.537 & Levoglucosenone & 1.93 & - & 1.28 \\
\hline 31 & 16.857 & Linoleic acid & 16.49 & 10.23 & 4.28 \\
\hline 32 & 16.534 & Luteolin 6,8-C-diglucoside & 0.99 & 1.98 & 2.21 \\
\hline 33 & 9.8 & Malonamic acid & - & 2.32 & - \\
\hline 34 & 4.56 & Methionine & - & 6.45 & - \\
\hline 35 & 15.419 & Methyl 17-methyloctadecanoate & 1.16 & - & 0.61 \\
\hline 36 & 6.158 & Methyl cuminate & - & 2.69 & - \\
\hline 37 & 3.913 & Methyl $\beta$-D-ribopyranoside & - & - & 13.42 \\
\hline 38 & 9.364 & N-Acetylneuraminic acid & 1.93 & - & 2.21 \\
\hline 39 & 9.5 & Nabilone & - & 1.73 & - \\
\hline 40 & 15.672 & Octadecanoic acid & 9.51 & 6.41 & 6.17 \\
\hline 41 & 8.65 & Octahyrochromen-2-one & 2.2 & - & - \\
\hline 42 & 4.942 & p-Allylphenol & 2.19 & 2.96 & 5.86 \\
\hline 43 & 7.886 & $p$-Cimene & - & - & 1.04 \\
\hline 44 & 5.559 & Phenylglyoxylic acid & 1.44 & - & - \\
\hline 45 & 13.05 & Quercetin $7,3^{\prime}, 4^{\prime}$-trimethoxy & - & 1.54 & 0.55 \\
\hline 46 & 8.919 & Resveratrol & - & - & 2.16 \\
\hline 47 & 23.623 & Rhodopin & - & 1.33 & 10.96 \\
\hline 48 & 6.328 & Sorbitol & 0.83 & - & - \\
\hline 50 & 4.38 & Sinapyl alcohol & - & 6.2 & - \\
\hline 51 & 5.57 & Sebacic acid & - & 3.24 & - \\
\hline 52 & 8.082 & Stevioside & 2.51 & - & - \\
\hline 53 & 10.36 & Tetra-O-methylfisetin & - & - & 0.33 \\
\hline 54 & 5.079 & Valproic acid & - & - & 13.44 \\
\hline 55 & 9.835 & Xanthinin & - & - & 4.99 \\
\hline 56 & 23.65 & Zeaxanthin & 1.63 & - & - \\
\hline 57 & 6.866 & $\alpha$-Bisabolol & - & - & 4.49 \\
\hline 58 & 13.241 & $\alpha$-Himachalene & - & - & 0.74 \\
\hline 59 & 8.14 & $\gamma$-Terpinene & - & - & 0.93 \\
\hline
\end{tabular}

The most abundant phenolic compound recorded in licorice peel extract was 3,5-dimethoxycinnamic acid (26.37\%), which could be used as an antimicrobial agent against the fungal pathogen $A$. flavus [96]. Most phenolic compounds (flavones, catechins, tannins, and quinines) interact with proteins and inactivate them by changing their conformation. Ali et al. [97] and Yazdani et al. [77] isolated different phenolic molecules from Piper betle extract, such as dihydrochalcone and chavibetol, both of which proved to have antifungal properties. Hua et al. [98] reported that the polyphenolic molecules could stop the A. flavus biosynthesis pathway of AFB1 by inhibiting norsolorinic acid accumulation. Aspartic acid (11.28\%) is also found in licorice extract, which acts as the building block of many essential amino acids such as lysine, threonine, and methionine. Moreover, it contains the energy source linoleic acid $(10.23 \%)$, which is responsible for maintaining a certain level of membrane fluidity of the transdermal water barrier of the epidermis. The antifungal activities exhibited by linolenic acid and $p$-allylphenol may be valuable alternatives for controlling plant pathogens, such as Botrytis cinerea, which is associated with increasing fungal oxygen uptake by $19.58 \%$ at $5 \mathrm{ppm}$ and exhibits fungicidal activities against several genera, including Alternaria and Sclerotinia [99,100]. In the same way, some derivatives of linoleic acid can suppress the AFB1 biosynthesis produced by different species of the genus Aspergillus [101]. 
Meanwhile, 3,5-dimethoxycinnamic acid may exhibit antimicrobial properties and inhibit Botrytis cinerea fungal growth [102]. Moreover, the licorice extract contains $6.45 \%$ methionine and $6.41 \%$ octadecanoic acid. Regarding banana peel extract, 31 components were identified and quantified; among these compounds, valproic acid exhibited the highest concentration of $13.44 \%$, followed by $13.42 \%$ methyl $\beta$-D-ribopyranoside. In addition, rhodopin and deoxyribose comprise $10.96 \%$ and $7.14 \%$, respectively (Table 6). Sadhasivam et al. [103] found that the pomegranate peel extract contains many phenolic and fatty acids and it reduces A. flavus AFB1 production up to $97 \%$. On the other hand, they noticed that the combined treatment (low doses of pomegranate peel extract and azole fungicide prochloraz) resulted in complete inhibition of toxin production over $72 \mathrm{~h}$ of treatment. They also showed a downregulation of most of the aflatoxin biosynthetic cluster genes [103]. Youssef et al. [49] suggested that the antimicrobial compounds (1-dodecanamine, n,ndimethyl, hexadecanoic acid, methyl ester, and $n$-hexadecanoic acid) found in the GCMS analysis of beetroot methanol and ethanol extracts could have potential activity on mycotoxin production. Finally, the results suggested that the three plant peel extracts could be promising sources for developing potentially effective and environmentally safer alternative ways to control aflatoxin formation, and they could create a potentially protective method for grain storage.

\section{Conclusions}

Among four solvent extracts of licorice, doum, and banana peels, the $75 \%$ licorice diethyl ether extract was intensely active, showing the best wet and dry weight inhibition of maize aflatoxigenic fungus, Aspergillus flavus; it also exhibited the highest efficacy ratio $(91 \%)$. Regarding aflatoxin $B_{1}$ production, all the tested plant extracts were effective against AFB1 production after one month of maize storage, with average efficacy ratios ranging from $74.1 \%$ to $97.5 \%$ compared with Thiram fungicide (20.1\%). The relative expression levels of aflD, aflP, aflQ, aflR, and aflS were significantly downregulated compared to untreated maize grains or Thiram-treated maize grains. Dimethoxycinnamic acid, aspartic acid, valproic acid, and linoleic acid found in GC-MS analysis might provide the extracts with phenolic and antioxidant capacities towards fungal growth and aflatoxin biosynthesis.

Author Contributions: Conceptualization, N.H.Y. and S.I.B.; methodology, N.H.Y., A.A., S.H.Q., S.M., H.M.Z., M.M.E., I.A.E., and S.I.B.; software, A.A and H.M.Z.; validation, A.A., S.H.Q., and S.M.; formal analysis, A.A.H., and M.M.E.; resources, N.A.H.; data curation, S.I.B.; writing-original draft preparation, N.H.Y., M.M.E., S.S., A.A., I.A.E., and S.I.B.; writing-review and editing, I.A.E., S.H.Q., S.M., A.A., and S.I.B.; visualization, S.S.; supervision, S.I.B.; project administration, E.S.D.; funding acquisition, E.S.D. All authors have read and agreed to the published version of the manuscript.

Funding: The current work was funded by Taif University Researchers Supporting Project Number (TURSP-2020/85), Taif University, Taif, Saudi Arabia.

Institutional Review Board Statement: Not applicable.

Informed Consent Statement: Not applicable.

Data Availability Statement: All data reported here are available from the authors upon request.

Acknowledgments: The authors extend their appreciation to Taif University for funding the current work by Taif University Researchers Supporting Project Number (TURSP-2020/85), Taif University, Taif, Saudi Arabia.

Conflicts of Interest: The authors declare no conflict of interest.

\section{References}

1. Wu, F.; Bhatnagar, D.; Bui-Klimke, T.; Carbone, I.; Hellmich, R.; Munkvold, G.; Paul, P.; Payne, G.; Takle, E. Climate change impacts on mycotoxin risks in US maize. World Mycotoxin J. 2011, 4, 79-93. [CrossRef]

2. Perrone, G.; Haidukowski, M.; Stea, G.; Epifani, F.; Bandyopadhyay, R.; Leslie, J.F.; Logrieco, A. Population structure and aflatoxin production by Aspergillus Sect. Flavi from maize in Nigeria and Ghana. Food Microbiol. 2014, 41, 52-59. [CrossRef] [PubMed] 
3. Asters, M.C.; Williams, W.P.; Perkins, A.D.; Mylroie, J.E.; Windham, G.L.; Shan, X. Relating significance and relations of differentially expressed genes in response to Aspergillus flavus infection in maize. Sci. Rep. 2014, 4, 4815. [CrossRef]

4. Adhikari, B.N.; Bandyopadhyay, R.; Cotty, P.J. Degeneration of aflatoxin gene clusters in Aspergillus flavus from Africa and North America. AMB Express 2016, 6, 62. [CrossRef]

5. Suleiman, M.N.; Omafe, O.M. Activity of three medicinal plants on fungi isolated from stored maize seeds (Zea mays (L.). Glob. J. Med. Plant Res. 2013, 1, 77-81.

6. Pietri, A.; Bertuzzi, T.; Pallaroni, L.; Piva, G. Occurrence of mycotoxins and ergosterol in maize harvested over 5 years in northern Italy. Food Addit. Contam. 2004, 21, 479-487. [CrossRef]

7. Galvano, F.; Ritieni, A.; Piva, G.; Pietri, A. Mycotoxins in the human food chain. In The Mycotoxin Blue Book; Diaz, D.E., Ed.; Nottingham University Press: Nottingham, UK, 2005; Volume 1, pp. 187-224.

8. Strosnider, H.; Azziz-Baumgartner, E.; Banziger, M.; Bhat, R.V.; Breiman, R.; Brune, M.-N.; Decock, K.; Dilley, A.; Groopman, J.; Hell, K.; et al. Workgroup report: Public health strategies for reducing aflatoxin exposure in developing countries. Environ. Health Perspect. 2006, 114, 1898-1903. [CrossRef] [PubMed]

9. Ogodo, A.C.; Ugbogu, O.C. Public health significance of aflatoxin in food industry-A review. Eur. J. Clin. Biomed. Sci. 2016, 2, $51-58$.

10. Abdel-Kareem, M.M.; Rasmey, A.M.; Zohri, A.A. The action mechanism and biocontrol potentiality of novel isolates of Saccharomyces cerevisiae against the aflatoxigenic Aspergillus flavus. Lett. Appl. Microbiol. 2018, 68, 104-111. [CrossRef]

11. Gauthier, L.; Bonnin-Verdal, M.-N.; Marchegay, G.; Pinson-Gadais, L.; Ducos, C.; Richard-Forget, F.; Atanasova-Penichon, V. Fungal biotransformation of chlorogenic and caffeic acids by Fusarium graminearum: New insights in the contribution of phenolic acids to resistance to deoxynivalenol accumulation in cereals. Int. J. Food Microbiol. 2016, 221, 61-68. [CrossRef]

12. Lagogianni, C.; Tsitsigiannis, D. Effective chemical management for prevention of aflatoxins in maize. Phytopathol. Mediterr. 2018, 57, 186-197.

13. Kaur, R.; Kaur, H. The antimicrobial activity of essential oil and plant extracts of Woodfordia fruticosa. Arch. Appl. Sci. Res. 2010, 2, 302-309.

14. Ashmawy, N.A.; Behiry, S.I.; Ali, H.M.; Salem, M.Z.M. Evaluation of Tecoma stans and Callistemon viminalis extracts against potato soft rot bacteria in vitro. J. Pure Appl. Microbiol. 2014, 8, 667-673.

15. Abdelkhalek, A.; Salem, M.Z.; Kordy, A.M.; Salem, A.Z.; Behiry, S.I. Antiviral, antifungal, and insecticidal activities of Eucalyptus bark extract: HPLC analysis of polyphenolic compounds. Microb. Pathog. 2020, 147, 104383. [CrossRef] [PubMed]

16. Tagne, A.; Feujio, T.P.; Sonna, C. Essential oil and plant extracts as potential substitutes to synthetic fungicides in the control of fungi. In Proceedings of the International Conference Diversifying Crop Protection, La Grande Motte, France, 12-15 October 2008; pp. 12-15.

17. Ferrochio, L.; Cendoya, E.; Farnochi, M.C.; Massad, W.; Ramirez, M.L. Evaluation of ability of ferulic acid to control growth and fumonisin production of Fusarium verticillioides and Fusarium proliferatum on maize based media. Int. J. Food Microbiol. 2013, 167, 215-220. [CrossRef]

18. Martin, J.G.P.; Porto, E.; Corrêa, C.B.; Alencar, S.M.; Gloria, E.M.; Cabral, I.S.R.; Aquino, L.M. Antimicrobial potential and chemical composition of agro-industrial wastes. J. Nat. Prod. 2012, 5, 27-36.

19. Stabnikova, O.; Wang, J.-Y.; Ding, H.B.; Tay, J.-H. Biotransformation of vegetable and fruit processing wastes into yeast biomass enriched with selenium. Bioresour. Technol. 2005, 96, 747-751. [CrossRef]

20. García-Marino, M.; Rivas-Gonzalo, J.-C.; Ibáñez, E.; García-Moreno, C. Recovery of catechins and proanthocyanidins from winery by-products using subcritical water extraction. Anal. Chim. Acta 2006, 563, 44-50. [CrossRef]

21. Mohamed, S.; Hassan, Z.; Hamid, N.A. Antimicrobial activity of some tropical fruit wastes (guava, starfruit, banana, papaya, passionfruit, langsat, duku, rambutan and rambai). Pertanika 1994, 17, 219.

22. Hossain, M.A.; Ngo, H.H.; Guo, W.S.; Nguyen, T.V. Removal of copper from water by adsorption onto banana peel as bioadsorbent. Int. J. Geomate 2012, 2, 227-234. [CrossRef]

23. Oliveira, L.; Freire, C.S.R.; Silvestre, A.J.D.; Cordeiro, N. Lipophilic extracts from banana fruit residues: A source of valuable phytosterols. J. Agric. Food Chem. 2008, 56, 9520-9524. [CrossRef]

24. Lim, Y.; Lim, T.; Tee, J. Antioxidant properties of several tropical fruits: A comparative study. Food Chem. 2007, 103, 1003-1008. [CrossRef]

25. Chabuck, Z.A.G.; Al-Charrakh, A.H.; Hindi, N.K.K.; Hindi, S.K.K. Antimicrobial effect of aqueous banana peel extract, Iraq. Res. Gate. Pharm. Sci. 2013, 1, 73-75.

26. Singh, J.P.; Kaur, A.; Shevkani, K.; Singh, N. Influence of jambolan (Syzygium cumini) and xanthan gum incorporation on the physicochemical, antioxidant and sensory properties of gluten-free eggless rice muffins. Int. J. Food Sci. Technol. 2015, 50, 1190-1197. [CrossRef]

27. Praveena, M.; Prabha, M.S.; Ravi, I.; Vaganan, M.M. Anti-colorectal cancer properties of Hill banana (cv. Virupakshi AAB) fruits: An in vitro assay. ICAR Int. Bimon. 2018, 8, 47.

28. Bouchra, C.; Mohamed, A.; Mina, I.H.; Hmamouchi, M. Antifungal Activity of Essential Oils from Several Medicinal Plants against Four Postharvest Citrus Pathogens; Firenze University Press: Florence, Italy, 2003.

29. Shehata, M.G.; Badr, A.N.; El Sohaimy, S.A.; Asker, D.; Awad, T.S. Characterization of antifungal metabolites produced by novel lactic acid bacterium and their potential application as food biopreservatives. Ann. Agric. Sci. 2019, 64, 71-78. [CrossRef] 
30. Raynor, L.; Mitchell, A.; Walker, R. Antifungal activities of four fatty acids against plant pathogenic fungi. Mycopathology 2004, 157, 87-90. [CrossRef] [PubMed]

31. Yu, J. Current understanding on aflatoxin biosynthesis and future perspective in reducing aflatoxin contamination. Toxins 2012, 4, 1024-1057. [CrossRef]

32. Roze, L.V.; Hong, S.-Y.; Linz, J.E. Aflatoxin biosynthesis: Current frontiers. Annu. Rev. Food Sci. Technol. 2013, 4, 293-311. [CrossRef] [PubMed]

33. Ehrlich, K.C. Predicted roles of the uncharacterized clustered genes in aflatoxin biosynthesis. Toxins 2009, 1, 37-58. [CrossRef]

34. Liang, D.; Xing, F.; Selvaraj, J.N.; Liu, X.; Wang, L.; Hua, H.; Zhou, L.; Zhao, Y.; Wang, Y.; Liu, Y. Inhibitory effect of cinnamaldehyde, citral, and eugenol on aflatoxin biosynthetic gene expression and aflatoxin B1 biosynthesis in Aspergillus flavus. J. Food Sci. 2015, 80, M2917-M2924. [CrossRef] [PubMed]

35. Caceres, I.; El Khoury, R.; Medina, Á.; Lippi, Y.; Naylies, C.; Atoui, A.; El Khoury, A.; Oswald, I.P.; Bailly, J.-D.; Puel, O. Deciphering the anti-aflatoxinogenic properties of eugenol using a large-scale q-PCR approach. Toxins 2016, 8, 123. [CrossRef]

36. El Khoury, R.; Caceres, I.; Puel, O.; Bailly, S.; Atoui, A.; Oswald, I.P.; El Khoury, A.; Bailly, J.-D. Identification of the antiaflatoxinogenic activity of Micromeria graeca and elucidation of its molecular mechanism in Aspergillus flavus. Toxins 2017, 9, 87. [CrossRef] [PubMed]

37. Samson, R.A.; Hoekstra, E.S.; Frisvad, J.C.; Filtenborg, O. Introduction to Food and Airborne Fungi; Centraalbureau voor Schimmelcultures: Utrecht, The Netherlands, 2004; Volume 4, pp. 169-172.

38. Klich, M.A. Identification of Common Aspergillus Species; Centraalbureau voor Schimmelcultures: Utrecht, The Netherlands, 2002; ISBN 9070351463.

39. Alshannaq, A.F.; Gibbons, J.G.; Lee, M.-K.; Han, K.-H.; Hong, S.-B.; Yu, J.-H. Controlling aflatoxin contamination and propagation of Aspergillus flavus by a soy-fermenting Aspergillus oryzae strain. Sci. Rep. 2018, 8, 1-14. [CrossRef]

40. Velluti, A.; Sanchis, V.; Ramos, A.J.; Egido, J.; Marın, S. Inhibitory effect of cinnamon, clove, lemongrass, oregano and palmarose essential oils on growth and fumonisin B1 production by Fusarium proliferatum in maize grain. Int. J. Food Microbiol. 2003, 89, 145-154. [CrossRef]

41. Salem, M.Z.M.; Behiry, S.I.; EL-Hefny, M. Inhibition of Fusarium culmorum, Penicillium chrysogenum and Rhizoctonia solani by n-hexane extracts of three plant species as a wood-treated oil fungicide. J. Appl. Microbiol. 2019, 126, 1683-1699. [CrossRef]

42. Abdelkhalek, A.; Behiry, S.I.; Al-Askar, A.A. Bacillus velezensis PEA1 inhibits Fusarium oxysporum growth and induces systemic resistance to cucumber mosaic virus. Agronomy 2020, 10, 1312. [CrossRef]

43. Di Pinto, A.; Forte, V.; Guastadisegni, M.C.; Martino, C.; Schena, F.P.; Tantillo, G.M. A comparison of DNA extraction methods for food analysis. Food Control 2007, 18, 76-80. [CrossRef]

44. Turkmen, N.; Sari, F.; Velioglu, Y.S. Effects of extraction solvents on concentration and antioxidant activity of black and black mate tea polyphenols determined by ferrous tartrate and Folin-Ciocalteu methods. Food Chem. 2006, 99, 835-841. [CrossRef]

45. Farahmandfar, R.; Asnaashari, M.; Sayyad, R. Comparison antioxidant activity of Tarom Mahali rice bran extracted from different extraction methods and its effect on canola oil stabilization. J. Food Sci. Technol. 2015, 52, 6385-6394. [CrossRef]

46. Asnaashari, M.; Farhoosh, R.; Sharif, A. Antioxidant activity of gallic acid and methyl gallate in triacylglycerols of Kilka fish oil and its oil-in-water emulsion. Food Chem. 2014, 159, 439-444. [CrossRef]

47. Okla, M.K.; Alamri, S.A.; Salem, M.Z.; Ali, H.M.; Behiry, S.I.; Nasser, R.A.; Alaraidh, I.A.; Al-Ghtani, S.M.; Soufan, W. Yield, phytochemical constituents, and antibacterial activity of essential oils from the leaves/twigs, branches, branch wood, and branch bark of sour orange (Citrus aurantium L.). Processes 2019, 7, 363. [CrossRef]

48. Abdelkhalek, A.; Salem, M.Z.M.; Hafez, E.; Behiry, S.I.; Qari, S.H. The phytochemical, antifungal, and first report of the antiviral properties of Egyptian Haplophyllum tuberculatum extract. Biology 2020, 9, 248. [CrossRef] [PubMed]

49. Youssef, N.H.; Qari, S.H.; Behiry, S.I.; Dessoky, E.S.; El-Hallous, E.I.; Elshaer, M.M.; Kordy, A.; Maresca, V.; Abdelkhalek, A.; Heflish, A.A. Antimycotoxigenic activity of beetroot extracts against Altenaria alternata mycotoxins on potato crop. Appl. Sci. 2021, 11, 4239. [CrossRef]

50. Hoeltz, M.; Welke, J.E.; Noll, I.B.; Dottori, H.A. Photometric procedure for quantitative analysis of aflatoxin B1 in peanuts by thin-layer chromatography using charge coupled device detector. Química Nova 2010, 33, 43-47. [CrossRef]

51. Adi, P.J.; Matcha, B. Analysis of aflatoxin B1 in contaminated feed, media, and serum samples of Cyprinus carpio L. by highperformance liquid chromatography. Food Qual. Saf. 2018. [CrossRef]

52. Abdelkhalek, A.; Sanan-Mishra, N. Differential expression profiles of tomato miRNAs induced by tobacco mosaic virus. J. Agric. Sci. Technol. 2019, 21.

53. Hafez, E.E.; El-Morsi, A.A.; El-Shahaby, O.A.; Abdelkhalek, A. Occurrence of Iris yellow spot virus from onion crops in Egypt. VirusDisease 2014, 25, 455-459. [CrossRef]

54. Abdelkhalek, A.; Elmorsi, A.; Alshehaby, O.; Sanan-Mishra, N.; Hafez, E. Identification of genes differentially expressed in onion infected with Iris yellow spot virus. Phytopathol. Mediterr. 2018, 57. [CrossRef]

55. Abo-Zaid, G.; Matar, S.; Abdelkhalek, A. Induction of plant resistance against tobacco mosaic virus using the biocontrol agent Streptomyces cellulosae isolate Actino 48. Agronomy 2020, 10, 1620. [CrossRef]

56. Abdelkhalek, A.; Al-Askar, A.A.; Hafez, E. Differential induction and suppression of the potato innate immune system in response to Alfalfa mosaic virus infection. Physiol. Mol. Plant Pathol. 2020, 110, 101485. [CrossRef] 
57. Livak, K.J.; Schmittgen, T.D. Analysis of relative gene expression data using real-time quantitative PCR and the $2-\Delta \Delta C T$ method. Methods 2001, 25, 402-408. [CrossRef]

58. Gomez, K.A.; Gomez, A.A. Statistical Procedures for Agricultural Research; John Wiley and Sons: Hoboken, NJ, USA, 1984; ISBN 0471870927.

59. McDonald, J.H. Handbook of Biological Statistics; Sparky House Publishing: Baltimore, MD, USA, 2009 ; Volume 2.

60. Al-Huqail, A.A.; Behiry, S.I.; Salem, M.Z.M.; Ali, H.M.; Siddiqui, M.H.; Salem, A.Z.M. Antifungal, antibacterial, and antioxidant activities of Acacia Saligna (Labill.) H.L. Wendl flower extract: HPLC analysis of phenolic and flavonoid compounds. Molecules 2019, 24, 700. [CrossRef]

61. Hojo, H.; Sato, J. Antifungal activity of licorice (Glycyrrhiza glabra) and potential applications in beverage, foods. J. Food Ingred. 2002, 203, 27-33.

62. Mohseni, R.; Noorbakhsh, F.; Moazeni, M.; Omran, A.N.; Rezaie, S. Antitoxin characteristic of licorice extract: The inhibitory effect on aflatoxin production in Aspergillus parasiticus. J. Food Saf. 2014, 34, 119-125. [CrossRef]

63. El Zawawy, N.A. Antioxidant, antitumor, antimicrobial studies and quantitative phytochemical estimation of ethanolic extracts of selected fruit peels. Int. J. Curr. Microbiol. Appl. Sci. 2015, 4, 298-309.

64. Olakunle, O.; Deborah, J.; Irene, O. Antifungal activity and phytochemical analysis of selected fruit peels. J. Biol. Med. 2019, 3, 040-043. [CrossRef]

65. Behiry, S.I.; Okla, M.K.; Alamri, S.; El-Hefny, M.; Salem, M.Z.M.; Alaraidh, I.A.; Ali, H.M.; Al-Ghtani, S.M.; Monroy, J.C.; Salem, A.Z.M. Antifungal and antibacterial activities of wood treated with Musa paradisiaca L. peel extract: HPLC analysis of phenolic and flavonoid contents. Processes 2019, 7, 215. [CrossRef]

66. Taha, G.A.; Abdel-Farid, I.B.; Elgebaly, H.A.; Mahalel, U.A.; Sheded, M.G.; Bin-Jumah, M.; Mahmoud, A.M. Metabolomic profiling and antioxidant, anticancer and antimicrobial activities of Hyphaene thebaica. Processes 2020, 8, 266. [CrossRef]

67. Abdallah, E.M. Screening of methanolic extract for antimicrobial activity of Hyphaene thebaica L. fruit pulp from Sudanese folklore. South Asian J. Res. Microbiol. 2021, 9, 6-12. [CrossRef]

68. Okorondu, S.I.; Sokari, T.G.; Akujobi, C.O.; Braide, W. Phytochemical and antibacterial properties of Musa paradisiaca stalk plant. Int. J. Biol. Sci. 2010, 2, 128-132.

69. Borges, C.V.; Amorim, V.B.D.O.; Ramlov, F.; Ledo, C.A.D.S.; Donato, M.; Maraschin, M.; Amorim, E.P. Characterisation of metabolic profile of banana genotypes, aiming at biofortified Musa spp. cultivars. Food Chem. 2014, 145, 496-504. [CrossRef]

70. Naik, P.; Wedel, M.; Bacon, L.; Bodapati, A.; Bradlow, E.; Kamakura, W.; Kreulen, J.; Lenk, P.; Madigan, D.M.; Montgomery, A. Challenges and opportunities in high-dimensional choice data analyses. Mark. Lett. 2008, 19, 201-213. [CrossRef]

71. Bernardo, J.S.; Sagum, R.S. Eggplant (Solanum melongena L.) peel as a potential functional ingredient in pan de sal. J. Nutr. Food Sci. 2016, 6. [CrossRef]

72. Adom, K.K.; Sorrells, A.M.E.; Liu, R.H. Phytochemicals and antioxidant activity of milled fractions of different wheat varieties. J. Agric. Food Chem. 2005, 53, 2297-2306. [CrossRef] [PubMed]

73. Laddomada, B.; Caretto, S.; Mita, G. Wheat bran phenolic acids: Bioavailability and stability in whole wheat-based foods. Molecules 2015, 20, 15666-15685. [CrossRef]

74. Gemeda, N.; Woldeamanuel, Y.; Asrat, D.; Debella, A. Effect of essential oils on Aspergillus spore germination, growth and mycotoxin production: A potential source of botanical food preservative. Asian Pac. J. Trop. Biomed. 2014, 4, S373-S381. [CrossRef]

75. El-Aziz, A.R.M.A.; Mahmoud, M.A.; Al-Othman, M.R.; Al-Gahtani, M.F. Use of selected essential oils to control aflatoxin contaminated stored cashew and detection of aflatoxin biosynthesis gene. Sci. World J. 2015, 2015, 1-13. [CrossRef] [PubMed]

76. Mabrouk, S.S.; El-Shayeb, N.M.A. Isolation of inhibitors of Aspergillus flavus from lentils (Lens culinris Medicus). In Proceedings of the 5th International Symposium on Mycotoxins and Phycotoxins, Vienna, Austria, 18-21 September 1982.

77. Yazdani, D.; Ahmad, Z.A.M.; How, T.Y.; Jaganath, I.B.; Shahnazi, S. Inhibition of aflatoxin biosynthesis in Aspergillus flavus by phenolic compounds extracted of Piper betle L. Iran. J. Microbiol. 2013, 5, 428-433.

78. Cleveland, T.E.; Yu, J.; Fedorova, N.; Bhatnagar, D.; Payne, G.A.; Nierman, W.C.; Bennett, J.W. Potential of Aspergillus flavus genomics for applications in biotechnology. Trends Biotechnol. 2009, 27, 151-157. [CrossRef] [PubMed]

79. Yu, J.; Fedorova, N.D.; Montalbano, B.G.; Bhatnagar, D.; Cleveland, T.E.; Bennett, J.W.; Nierman, W.C. Tight control of mycotoxin biosynthesis gene expression in Aspergillus flavus by temperature as revealed by RNA-Seq. FEMS Microbiol. Lett. 2011, 322, 145-149. [CrossRef]

80. Lappa, I.K.; Dionysopoulou, A.M.; Paramithiotis, S.; Georgiadou, M.; Drosinos, E.H. Dual transcriptional profile of Aspergillus flavus during co-culture with Listeria monocytogenes and aflatoxin B1 production: A pathogen-pathogen interaction. Pathogens 2019, 8, 198. [CrossRef] [PubMed]

81. Ullah, N.; Akhtar, K.P.; Hassan, S.W.U.; Asi, M.R.; Sadef, Y. First report of molecular characterization of Aspergillus flavus from maize in Pakistan. J. Plant Pathol. 2019, 101, 1289-1290. [CrossRef]

82. Papa, K.E. Norsolorinic acid mutant of Aspergillus flavus. Microbiology 1982, 128, 1345-1348. [CrossRef]

83. Bhatnagar, D.; Ehrlich, K.C.; Cleveland, T.E. Molecular genetic analysis and regulation of aflatoxin biosynthesis. Appl. Microbiol. Biotechnol. 2003, 61, 83-93. [CrossRef] [PubMed]

84. Scherm, B.; Palomba, M.; Serra, D.; Marcello, A.; Migheli, Q. Detection of transcripts of the aflatoxin genes aflD, aflO, and aflP by reverse transcription-polymerase chain reaction allows differentiation of aflatoxin-producing and non-producing isolates of Aspergillus flavus and Aspergillus parasiticus. Int. J. Food Microbiol. 2005, 98, 201-210. [CrossRef] [PubMed] 
85. Verheecke, C.; Liboz, T.; Anson, P.; Zhu, Y.; Mathieu, F. Streptomyces-Aspergillus flavus interactions: Impact on aflatoxin B accumulation. Food Addit. Contam. Part A 2015, 32, 572-576. [CrossRef] [PubMed]

86. Mayer, Z.; Färber, P.; Geisen, R. Monitoring the production of aflatoxin B1 in wheat by measuring the concentration of nor-1 mRNA. Appl. Environ. Microbiol. 2003, 69, 1154-1158. [CrossRef] [PubMed]

87. Rodrigues, P.; Venâncio, A.; Kozakiewicz, Z.; Lima, N. A polyphasic approach to the identification of aflatoxigenic and nonaflatoxigenic strains of Aspergillus Section Flavi isolated from Portuguese almonds. Int. J. Food Microbiol. 2009, 129, $187-193$. [CrossRef]

88. Sweeney, M.J.; Pàmies, P.; Dobson, A.D. The use of reverse transcription-polymerase chain reaction (RT-PCR) for monitoring aflatoxin production in Aspergillus parasiticus 439. Int. J. Food Microbiol. 2000, 56, 97-103. [CrossRef]

89. Degola, F.; Berni, E.; Spotti, E.; Ferrero, I.; Restivo, F.M. Facing the problem of "false positives": Re-assessment and improvement of a multiplex RT-PCR procedure for the diagnosis of A. flavus mycotoxin producers. Int. J. Food Microbiol. 2009, 129, 300-305. [CrossRef]

90. Dai, J.; Mumper, R.J. Plant phenolics: Extraction, analysis and their antioxidant and anticancer properties. Molecules 2010, 15, 7313-7352. [CrossRef] [PubMed]

91. Blois, M.S. Antioxidant determinations by the use of a stable free radical. Nat. Cell Biol. 1958, 181, 1199-1200. [CrossRef]

92. Hsu, B.; Coupar, I.M.; Ng, K. Antioxidant activity of hot water extract from the fruit of the Doum palm, Hyphaene thebaica. Food Chem. 2006, 98, 317-328. [CrossRef]

93. Satish, S.; Mohana, D.C.; Ranhavendra, M.P.; Raveesha, K.A. Antifungal activity of some plant extracts against important seed borne pathogens of Aspergillus sp. J. Agric. Technol. 2007, 3, 109-119.

94. González-Montelongo, R.; Lobo, M.G.; González, M. Antioxidant activity in banana peel extracts: Testing extraction conditions and related bioactive compounds. Food Chem. 2010, 119, 1030-1039. [CrossRef]

95. Fatemeh, S.R.; Saifullah, R.; Abbas, F.M.A.; Azhar, M.E. Total phenolics, flavonoids and antioxidant activity of banana pulp and peel flours: Influence of variety and stage of ripeness. Int. Food Res. J. 2012, 19, 1041.

96. Qadeer, G.; Rama, N.H.; Zareef, M.; Al-Masoudi, N.P. Antibacterial, antifungal, antiherbicidal, and antifungicidal activity of 4,6-dimethoxyhomophthalic acid and related compounds. Pharm. Chem. J. 2008, 42, 335-339. [CrossRef]

97. Ali, I.; Khan, F.G.; Suri, K.A.; Gupta, B.D.; Satti, N.K.; Dutt, P.; Afrin, F.; Qazi, G.N.; Khan, I.A. In vitro antifungal activity of hydroxychavicol isolated from Piper betle L. Ann. Clin. Microbiol. Antimicrob. 2010, 9, 7. [CrossRef]

98. Hua, S.T.; Grosjean, O.K.; Baker, J.L. Inhibition of aflatoxin biosynthesis by phenolic compounds. Lett. Appl. Microbiol. 1999, 29, 289-291. [CrossRef]

99. Calvo, H.; Marco, P.; Blanco, D.; Oria, R.; Venturini, M. Potential of a new strain of Bacillus amyloliquefaciens BUZ-14 as a biocontrol agent of postharvest fruit diseases. Food Microbiol. 2017, 63, 101-110. [CrossRef]

100. Liu, B.; Qiao, H.; Huang, L.; Buchenauer, H.; Han, Q.; Kang, Z.; Gong, Y. Biological control of take-all in wheat by endophytic Bacillus subtilis E1R-j and potential mode of action. Biol. Control 2009, 49, 277-285. [CrossRef]

101. Christensen, S.A.; Kolomiets, M.V. The lipid language of plant-fungal interactions. Fungal Genet. Biol. 2011, 48, 4-14. [CrossRef] [PubMed]

102. Vio-Michaelis, S.; Apablaza-Hidalgo, G.; Gómez, M.; Peña-Vera, R.; Montenegro, G. Antifungal activity of three Chilean plant extracts on Botrytis cinerea. Bot. Sci. 2012, 90, 179. [CrossRef]

103. Sadhasivam, S.; Shapiro, O.H.; Ziv, C.; Barda, O.; Zakin, V.; Sionov, E. Synergistic inhibition of mycotoxigenic fungi and mycotoxin production by combination of pomegranate peel extract and azole fungicide. Front. Microbiol. 2019, 10, 1919. [CrossRef] [PubMed] 